\title{
Northern Sea Route Permit Scheme: Does Article 234 of UNCLOS Allow Prior Authorization?
}

\author{
Jan Jakub Solski* \\ Norwegian Centre for the Law of the Sea, Faculty of Law, UiT - The Arctic University of Norway, \\ Tromsø, Norway
}

Note: This article has been published as Jan Jakub Solski, "Northern Sea Route Permit Scheme: Does Article 234 of UNCLOS Allow Prior Authorization?" Ocean Yearbook 35 (1) (2021): 443-472.

\section{INTRODUCTION}

The legislation of Russia and Canada includes a veiled requirement to obtain prior authorization from the coastal State for merchant ships to navigate through large areas in the Arctic. The coastal State concept of prior authorization presupposes that a coastal State may legally give or withhold its consent to the passage of a vessel. In areas where flag States enjoy navigational rights or freedoms, the notion that a coastal State may exercise authority to give or withdraw consent is controversial. While there are clear situations where coastal authorization is legally valid, for example, entry into a State's internal waters, there is no international legal instrument related to navigation that refers to prior authorization. Both Russia and Canada view Article 234 of the United Nations Convention on the Law of the Sea (UNCLOS) ${ }^{1}$ as providing the international legal basis for this measure. ${ }^{2}$ Other States have protested Canada's and Russia's requirements, however, ships of many flag States have sought permits from the respective coastal administrations.

Article 234, the Arctic lex specialis, allows a coastal State to prescribe and enforce laws and regulations to prevent, reduce and control vessel-source pollution in ice-covered areas. The laws and regulations are to be non-discriminatory and have due regard to navigation and the protection and preservation of the marine environment based on the best available scientific evidence. Article 234 does not offer a precise answer to accommodating the balance of two interests: navigation and the protection and preservation of the marine environment. The imprecise wording that limits coastal State discretion under Article 234 suggests a standard of reasonableness, whereby the consistency with international law of specific measures undertaken by the coastal State is to be assessed on a case-bycase basis. In the abstract, the evaluation of the reasonableness of a measure will depend on the treaty

\footnotetext{
${ }^{*}$ Research for this article has been financed by the Norruss Pluss programme of the Research Council of Norway through support for the research project Regulating shipping in Russian Arctic Waters: Between international law, national interests and geopolitics, project. No. 287576.

To the extend this article relies on my PhD thesis, I am grateful for the excellent guidance of my supervisors Professor Erik Jaap Molenaar and Professor Erik Franckx, as well as the constructive feedback from my opponent during the PhD defense Professor Ted McDorman, and the anonymous reviewers for their comments on the draft of this article.

1 United Nations Convention on the Law of the Sea (adopted 10 December 1982, entered into force 16 November 1994) 1833 United Nations Treaty Series 3.

${ }^{2}$ For the determination of Russia's position, it is helpful to consult the statement by the Administration of the Northern Sea Route (ANSR). In the note handed to the Arctic Sunrise and published on its website, see Notification No. 77, September 20, 2013, on file with the author, the ANSR stated that the ship was refused a permit on the grounds that there had been a:

Violation of the Rules of navigation in the water area of the NSR, adopted and enforced by the Russian Federation in accordance with the article 234 of the United Nations Convention on the Law of the Sea, 1982,_ navigation in the water area of the Northern Sea Route from 24.08.2013 to 27.08.2013 without permission of the Northern Sea Route Administration, as well as taken actions in this [sic] creating potentially [sic] threat of marine pollution in the water area of the Northern Sea Route, ice-covered for most part of the year.

Canada stated that Article 234 "provides a complete legal justification" in international law for Northern Canada Vessel Traffic Services Zone Regulations (NORDREG). See IMO Doc. MSC 88/11/3, October 5, 2010, para. 5.
} 
wording and the interaction of two factors: the contribution of the measure to the goal of Article 234, and the effect of the measure on the exercise of the navigational right or freedom.

Article 234 has been used as justification for specific laws and regulations adopted by Canada and Russia. Some other Arctic States might follow suit in the future, although only Denmark (on behalf of Greenland) has indicated an interest in doing so by drafting relevant legislation. ${ }^{3}$ Norway could potentially apply Article 234 within ice-covered areas adjacent to Svalbard, but this would be problematic as Norway has not established an exclusive economic zone (EEZ) for this area. ${ }^{4}$ The United States might also be able to utilize Article 234 off the coasts of Alaska.

The question this article will address is whether prior authorization, as practiced by Russia within the Northern Sea Route (NSR) regime, is consistent with Article 234. The article is structured as follows. The first two sections briefly present the respective legislation of Russia and Canada. The article then aims to investigate prior authorization for ice-covered areas in the context of the debates on prior authorization outside of the Arctic and considering the general international law of the sea and State practice. Finally, the article provides a comprehensive discussion over the arguments for and against the consistency with Article 234 of the permit scheme as practiced by Russia in the NSR.

\section{PRIOR AUTHORIZATION IN RUSSIA'S ICE-COVERED AREAS}

The key Russian NSR legislation is the 1999 Merchant Shipping Code, ${ }^{5}$ and the 2013 Rules. ${ }^{6}$ Article 5.1(4) of the 1999 Merchant Shipping Code stipulates that the Administration of the NSR (ANSR) may issue permits for navigation on the NSR on the condition that the vessel complies with relevant requirements concerning safety of navigation and the protection of the marine environment. Items 4 and 5 of the 2013 Rules specify what information is required from the applicant, namely:

- Information about the ship and its voyage in accordance with Annex 1 of the 2013 Rules;

- A copy of the classification certificate or ship's letter;

- A copy of the tonnage certificate or ship's letter;

- Copies of documents certifying the availability of insurance of civil liability for pollution damage or any other damage inflicted by the ship established by international treaties of the Russian Federation and Russian legislation (these include the Civil Liability Certificate (CLC) and the Civil Liability for Bunker Oil Pollution Damage Certificate (CLBC);

- For ships making a single passage, a copy of the certificate from the classification society approving such a single passage;

- For ships carrying out towing, a copy of the certificate from the classification society approving the project of towing; and

- For ships to which the Polar Code applies, ${ }^{7}$ a copy of a Polar Ship Certificate.

The ANSR shall issue a permit based on an application transmitted electronically no earlier than 120 days and no later than 15 days before planned entry. ${ }^{8}$ The ANSR is to respond within ten days of

${ }^{3}$ T. Henriksen, "Norway, Denmark (in respect of Greenland) and Iceland," in Governance of Arctic Shipping: Balancing Rights and Interests of Arctic States and User States, eds., R.C. Beckman et al., (Leiden | Boston: Brill Nijhoff, 2017), [245-295], p. 277.

${ }^{4}$ Id., p. 253.

5 The Merchant Shipping Code of the Russian Federation, April 30, 1999, No. 81 FZ, SZRF, May 3, 1999 , No. 18 , p. 2207.

${ }^{6}$ Rules of Navigation in the Water Area of the Northern Sea Route, as approved by the order of the Ministry of Transport of Russia, January 17, 2013, No. 7, (2013 Rules).

${ }^{7}$ IMO, International Code for Ships Operating in Polar Waters (Polar Code), the text of the Polar Code is available in IMO Doc MEPC 68/21/Add.1, June 5, 2015, Annex 10, in force January 1, 2017 (Polar Code). 
the application, and is to publish the decision on its website. ${ }^{9}$ When the ANSR rejects an application, it is required to inform the applicant by email of the reasons for refusal. ${ }^{10}$ The scope of discretion of the ANSR in deciding on applications is narrow. The ANSR appears to be obliged to grant a permit once the ship has complied with the formal requirements. In summer (i.e., July to 15 November) any vessel can enter the NSR, provided they have managed to obtain relevant certificates, which are contingent on fulfilling substantive requirements. Outside this period, vessels need to have been granted a minimum ice class of Arc4. ${ }^{11}$ The legislation does not seem to allow the ANSR to deny a permit on other grounds - State security, for instance.

A recent study of the practice of the ANSR regarding the issuance of permits during 2013-2019 shows that, when the ANSR considers applications for navigation on the NSR, it acts transparently and predictably. ${ }^{12}$ The ANSR has rejected applications based on their incompleteness, with the usual reasons for rejections being lacking copies of documents, mistakes on the application forms or inconsistencies between the planned itinerary and the operational limits of the vessel determined based on relevant certificates, and the matrix of admissibility criteria from Annex 2 to the 2013 Rules ${ }^{13}$ All refusals, except the refusal of the fourth application of the Arctic Sunrise,${ }^{14}$ were clearly supported by non-compliance with the 2013 Rules. The number of refusals was lowest in 2016 and 2017, rising slightly in 2018, likely as a result of the entry into force of new amendments to the 2013 Rules, to drop again in 2019 (Figure 1). ${ }^{15}$ This trend indicates that the practice of the ANSR has become predictable and that interested companies learn how to file a correct application.

${ }^{8}$ Item 6 of the 2013 Rules (see n. 6 above). It is noteworthy that under the previously applicable 1990 Regulations for Navigation on the Seaways of the Northern Sea Route, approved on September 14, 1990, published on June 18, 1991 in 29 Izveshcheniya Moreplavatelyam (1990 Regulations), every vessel intending to navigate the NSR was required to undergo inspection in a Russian port and the application was required four months in advance. See, J.J. Solski, "Russia," in Governance of Arctic Shipping: Balancing Rights and Interests of Arctic States and User States, eds., R.C. Beckman et al., (Leiden | Boston: Brill Nijhoff, 2017), [173-216], pp. 197-8. As such, it is evident that the process has become unequivocally smoother for the ship operators.

${ }^{9}$ The ANSR keeps records of all the applications, permits and refusals on its website. Decisions regarding foreign vessels are published in English; the rest are published in Russian.

${ }^{10}$ Item 11 of the 2013 Rules. See n. 6 above.

${ }^{11}$ Arc4 used to be the minimum ice class requirement for ships to navigate on the NSR. See Item 2.2 of the 1996 Requirements for the Design, Equipment, and Supplies of Vessels Navigating the NSR. Note that the notations used in the 2013 Rules refer to the Rules for the Classification and Construction of Sea-Going Ships, developed by the Russian Maritime Register of Shipping.

12 J.J. Solski, "The Northern Sea Route in the 2010s: Development and implementation of the relevant law," Arctic Review on Law and Politics 11 (2020): 383-410.

${ }^{13}$ Annex 2, an integral part of the 2013 Rules, provides for specific "Criteria on the Admissibility of Ships to the NSR in Accordance with Ice Class.” These criteria comprise different categories of ships' ice class, periods of the year, ice conditions and the division of the NSR into seven zones. The matrix helps determine whether a specific ship can enter a specific zone and whether icebreaker assistance is necessary.

${ }^{14}$ The Arctic Sunrise, operated by Greenpeace International and classified by Det Norske Veritas (DNV) as an 'Icebreaker' and which, according to the DNV Rules (1973 Edition), was the second highest ice class at the time of construction, applied for but was refused a permit to enter the NSR four times in a row. After the third refusal, the Arctic Sunrise entered the NSR without authorization. In response to the fourth application, the ANSR denied a permit to the Arctic Sunrise on the grounds of the previous violation of the 2013 Rules, see Notification No. 77, September 20, 2013, see n. 2 above. Apart from the Arctic Sunrise, the ANSR never again used a prior violation of the 2013 Rules as grounds on which to reject an application, even though there were many instances where applicants obtained a permit despite having been previously identified for non-compliance by the ANSR. There have been examples where the ANSR could have raised this issue, but it did not. See Solski 2020, n. 12 above.

15 Amendments effected by the Order of the Ministry of Transport on the Introduction of Amendments to the Rules of Navigation in the water area of the Northern Sea Route, adopted by the Order of the Ministry of Transport of January 17, 2013, No. 7, January 9, 2017, No. 5, registered by the Ministry of Justice, March 7, 2017, No. 45866, requiring a Polar Ship Certificate as well as a ship's letter for smaller ships. 
Russian legislation is not very clear with regard to penalties for non-compliance with the requirement. The practice has been that when the ANSR identified non-compliance, it published information about the incident on its website, and informed the Federal Service for Supervision of Transport (Rostransnadzor) about the incident. ${ }^{16}$ There was not that much at-sea enforcement, rather an administrative investigation combined with the imposition of penalties after non-compliance has been ascertained. The penalties can be strikingly insignificant both for Russian-flagged ${ }^{17}$ and for foreign-flagged vessels. ${ }^{18}$ In addition, the practice in some specific cases shows a great deal of flexibility and a forgiving approach of the authorities to the violators. ${ }^{19}$

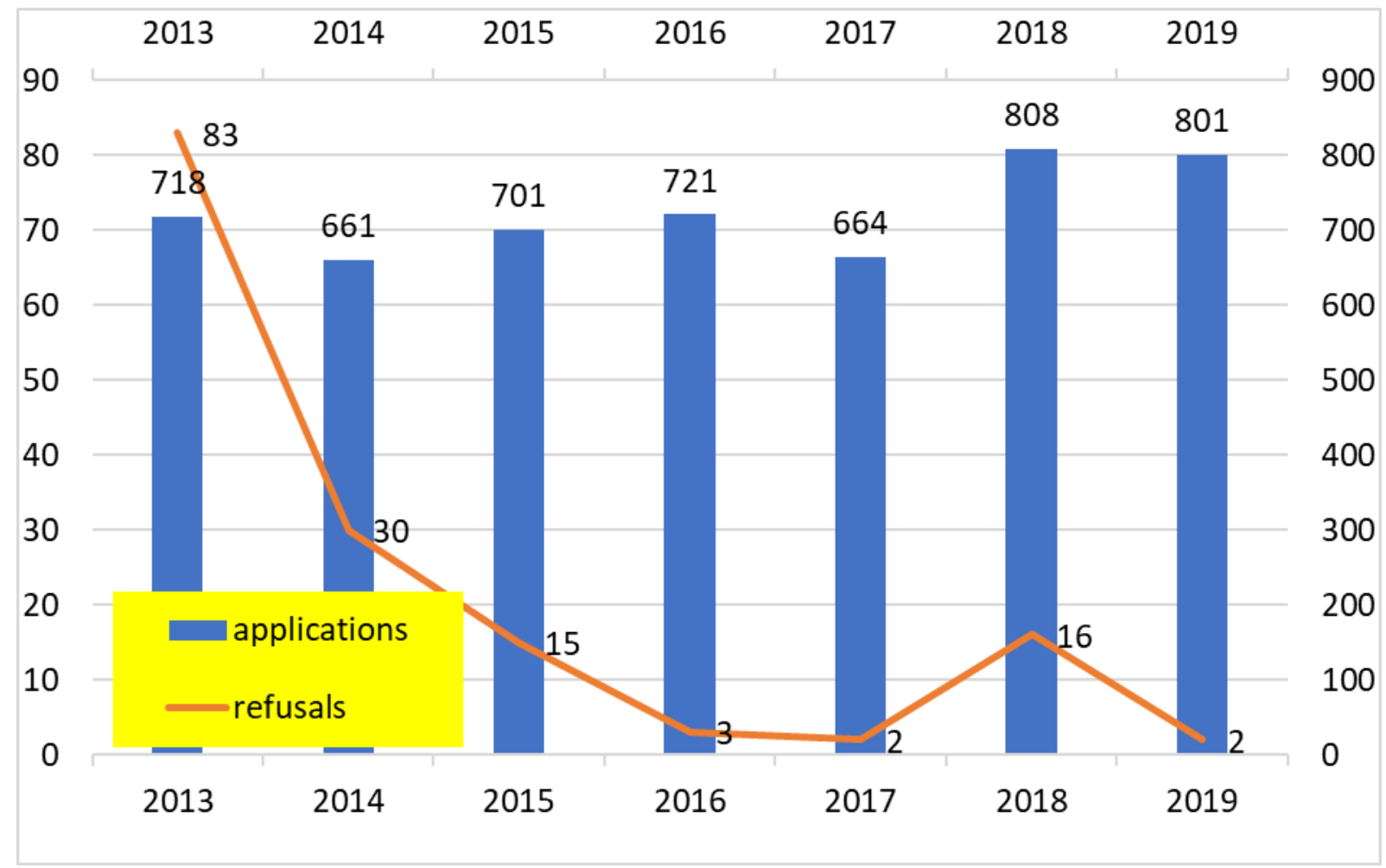

Table 1 The number of permit applications and refusals over the years.

\footnotetext{
${ }^{16}$ Solski, see n. 8 above, p. 210.

17 On August 2, 2016, the ANSR reported that the Russian-flagged Tovra entered the NSR on August 1, 2016 without a permit. Later, on October 27, 2016, Rostransnadzor reported that a person responsible for maritime safety and the prevention of pollution from the company Bunkernaya Kompaniya, S.V. Veretnikov was fined with RUB1,500 (which is approximately US\$20) based on Article 11.13(1) of the Code of Administrative Offences of the Russian Federation, December 30, 2001, No 195 FZ, Sobranie zakonodatel'stva Rossiyskoy Federatsii, January 7, 2012, No. 1, p. 1 (2001 CAO). The information was retrieved from <http://rostransnadzor.ru/informatsiya-o-kontrol-no-nadzornojdeyatel-nosti-gosmorrechnadzora-za-period-s-20oktyabrya-po-27-oktyabrya/>, which is no longer available on the Internet.

18 Non-compliance with the 2013 Rules by a ship master of a foreign vessel will likely constitute an administrative offense under Article 11.7 of the $2001 \mathrm{CAO}$, which deals with "violation[s] of the rules of navigation." Article 11.7(1) stipulates that a violation of the rules of navigation can lead to an imposition of an administrative fine of RUB500 to 1000 (which is approximately US\$15) or to the depravation of a right to sail a vessel for up to one year. However, it is doubtful that this can be imposed on foreign ship masters.

${ }^{19}$ One example is the Maltese-flagged Bozdag, which was reported on January 9, 2017 for navigating without a permit (after the previous permit expired). It is interesting to note that Gazprom Neft, representing Bozdag, applied for a new permit the same day it was reported for non-compliance. The ship obtained a new permit just the following day, January 10, 2017, see Russia, Ministry of Transport of the Russian Federation, Federal Agency for Sea and Inland Water Transport, Northern Sea Route Administration, 'Notification No 2/5,' January 10,2017 , on file with the author.
} 
The repeated refusals by the ANSR in respect of the Arctic Sunrise's intent to navigate the NSR was raised in the Dutch Parliament and the diplomatic exchange between the Netherlands and Russia. In the Dutch Parliament, Frans Timmermans, then the Dutch Minister of Foreign Affairs, emphasized that Article 234 does not give a coastal State an unfettered right to interfere with the freedom of navigation. ${ }^{20}$ This position was, according to Timmermans, presented to the Russian Embassy along with the request to provide an additional explanation of the reasons for the refusals. ${ }^{21}$

The United States expressed its position in a diplomatic note, which states

A unilateral, coastal State requirement for prior notification and permission to transit these areas does not meet the condition set forth in Article 234 of having due regard to navigation. The United States does not consider that Article 234 justifies a coastal State requirement for prior notification or permission to exercise navigation rights and freedoms. ${ }^{22}$

On the other hand, many foreign-flagged vessels that have used the NSR, including some government-owned vessels, ${ }^{23}$ have complied with Russian regulations, including the requirement of prior authorization.

\section{PRIOR AUTHORIZATION IN CANADA'S ICE-COVERED AREAS}

Article 126(3)(a) of the Canada Shipping Act, 2001 includes a requirement to obtain clearance before a vessel can enter, leave or proceed within a Vessel Traffic Services (VTS) Zone. The requirement applies in the entire VTS Zone, which extends to the waters of the Canadian Arctic archipelago and the Canadian EEZ. Contravention of the clearance obligation is an offense punishable by a fine of not more than CA $\$ 100,000$ and/or imprisonment of not more than one year. ${ }^{24}$ In addition, a vessel may be subject to detention. ${ }^{25}$

\footnotetext{
${ }^{20}$ Netherlands, "Vragen gesteld door de leden der Kamer, met de daarop door de regering gegeven antwoorden [Questions asked by the members of the House, with the answers given by the government]" Parliamentary Papers (2013-2014) Appendix no. 136, available online: <https://zoek.officielebekendmakingen.nl/ah-tk20132014-136.pdf>; see also E. Franckx, "The 'New' Arctic Passages and the 'Old' Law of the Sea," in Jurisdiction over Ships: Post-UNCLOS Developments in the Law of the Sea, ed. H. Ringbom (Leiden | Boston: Brill, 2015), [194-216], p. 209; A.G. Oude Elferink, "The Arctic Sunrise incident: A multi-faceted law of the sea case with a human rights dimension," International Journal of Marine and Coastal Law 29, no. 2 (2014): [244289], p. 248.

${ }^{21} \mathrm{Id}$.

${ }^{22}$ Diplomatic Note from the United States to Russia regarding the NSR (May 29, 2015) reproduced in C.D. Guymon ed., Digest of United States Practice in International Law 2015, p. 526, available online: <https://20092017.state.gov/documents/organization/258206.pdf $\geq$ [January 21, 2020] (2015 US Diplomatic Note to Russia).

${ }^{23}$ A vast majority of ships operating on the NSR belong to private companies. However, it is worth noting that a few government-owned vessels complied with Russian regulations. For instance, the German-flagged Polarstern, which according to the information at the ANSR website is owned by the German Federal Ministry of Education and Research, applied for and obtained permits in 2014, 2015, 2016 and 2018. However, the attribution of the application for the permit to the German Government may not be as straightforward as it seems, as it was the shipping company Reederei F. Laeisz that filed these applications. Interestingly, the application on behalf of the Chinese-flagged research vessel Xue Long was submitted in 2017 by the Polar Research Institute of China. The Polar Research Institute of China is not a private company, but its practices do not constitute State practice either.

${ }^{24}$ Article 138 (1) and (2) of the Canada Shipping Act, 2001, S.C. 2001, c. 26, available online: <https://lawslois.justice.gc.ca/eng/acts/C-10.15/index.html> (Canada Shipping Act, 2001).

${ }^{25}$ Id., art. 138 (4).
} 
The conditions for the granting or refusing of clearance are not set out in the Canada Shipping Act, 2001, but may be subject to further regulations, elaborated by the Governor in Council, on the recommendation of the Minister of Transport. ${ }^{26}$ McDorman mentions three relevant regulations: the Eastern Canada Vessel Traffic Services Zone Regulations, the Vessel Traffic Services Zone Regulations and the Northern Canada Vessel Traffic Services Zone Regulations (NORDREG) ${ }^{27}$ None of these regulations specify the conditions for the granting or refusal of clearance.

Consequently, the powers of Canada's marine communications and traffic services officers include broadly defined powers to grant clearance to a vessel to enter, leave or proceed within the VTS Zone $;{ }^{28}$ direct the vessel to leave the VTS Zone; ${ }^{29}$ or direct the vessel to leave or refrain from entering any specified area. ${ }^{30}$ It appears then that the discretion of the officers is unconstrained by other regulations.

After Canada announced its intention to revise NORDREG into a mandatory system, different aspects of this decision became the object of international scrutiny. The requirement of clearance was hardly in the limelight during the debate at the International Maritime Organization (IMO). The fundamental reason for this was the reality that the IMO was not a suitable forum for discussions on the interpretation of the provisions of UNCLOS or the international law of the sea in general. Nonetheless, the delegation of Singapore expressed its view on the requirement of clearance. The relevant statement of Singapore reads:

Even though Article 234 allows the coastal State to impose measures that would prevent, reduce and control marine pollution, these are to be done with 'due regard to navigation.' It is, however, not clear to this delegation how the proposed requirement for clearance would adequately give 'due regard to navigation. ${ }^{31}$

The requirement to obtain clearance was raised by the United States in its 2010 Diplomatic Note to Canada. The U.S. position expressed in the note is as follows:

The requirement for foreign vessels to obtain Canadian permission to enter and transit certain areas within Canada's EEZ and territorial sea, including possible enforcement, is not consistent with the freedom of navigation within the EEZ, the right of innocent passage in the territorial sea, or the right of transit passage, all of which are bedrock principles of the law of the sea. ${ }^{32}$

The 2010 French Note Verbale to Canada does not explicitly refer to "clearance," but it follows from the Note that France considers the legislation to be contrary to the provisions of UNCLOS on the freedom of navigation and innocent passage since it unilaterally imposes restrictions that may lead to

\footnotetext{
${ }^{26}$ Id., art. $136(1)(\mathrm{c})$.

${ }^{27}$ T.L. McDorman, "Canada's vessel traffic management regime: An overview in the context of international law," in The Regulation of International Shipping: International and Comparative Perspectives: Essays in Honor of Edgar Gold, eds., A. Chircop, N. Letalik, T.L. McDorman and S. Rolston ( Leiden | Boston: Martinus Nijhoff Publishers, 2012), [509-524], p. 516.

${ }^{28}$ Article 126 (3) (a) of the Canada Shipping Act, 2001, see n. 24 above.

${ }^{29}$ Id., art. $126(3)$ (d) (i).

${ }^{30}$ Id., art. 126(3) (d) (ii).

${ }^{31}$ The text of Singapore's statement is available in Annex 28 of the IMO Doc. MSC 88/26, December 15, 2010.

32 USA, "Diplomatic Note from the US Embassy, Ottawa, Canada to Department of Foreign Affairs and International Trade of Canada" (18 August 2010), available online: <https://2009-
} 2017.state.gov/documents/organization/179287.pdf>. 
the prohibition of passage or access. ${ }^{33}$ It is unknown whether other States protested Canada's requirement of clearance. ${ }^{34}$

\section{PRIOR AUTHORIZATION IN UNCLOS AND STATE PRACTICE}

That there is a duty on a coastal State not to interfere with the exercise of a navigational right is clear in the relevant provisions of UNCLOS. In the territorial sea, the coastal State has an explicit duty not to hamper innocent passage, and a duty not to impose requirements that have a practical effect of denying or impairing the right of innocent passage. ${ }^{35}$ In the same vein, a State bordering a strait used for international navigation has an explicit duty not to hamper transit passage, ${ }^{36}$ and the laws and regulations adopted by it are not to have a practical effect of denying, hampering or impairing the right of transit passage. ${ }^{37}$ The competence of a coastal State to temporarily suspend innocent passage in specified areas under Article 25(3) arises in exceptional situations, and as such, it does not challenge the underlying architecture of the correlation between the right and the duty.

Although it is often challenging to understand what activity of a coastal State would amount to a breach of the duty not to hamper passage, nevertheless the language in the Convention indicates that when a flag State enjoys a right of passage, be it innocent or transit passage, a coastal State has also a duty not to prevent it.

UNCLOS refers to the freedom of navigation as a "freedom" in Article 87(1)(a), but also as a "right" in Article $90 .{ }^{38}$ In addition, Articles 56 and 58 speak of "rights" and "duties" of other States in the EEZ, instead of consistently referring to "freedom." This suggests that a freedom is a broader notion that comprises the relevant right. The correlated duty of the coastal State vis-à-vis the flag State exercising the (right of the) freedom of navigation is expressed differently than an explicit duty not to hamper or deny. Article 56(2) in conjunction with Articles 58(1) and 87(1) refer to a due regard duty. Although the wording is less definite semantically than a duty not to hamper, this may be the result of the compromise on the sui generis status of the EEZ, rather than an expression of the intention to provide for a more limited privilege of navigation outside the territorial sea. One can argue that such a formulation is not necessary because of the sui generis nature of the EEZ and that in the EEZ, the coastal State can interfere with the freedom of navigation as long as, and only when, it has jurisdiction provided for in the relevant provisions of the Convention. Consequently, the freedom of navigation does not need to be framed as a right to obtain due protection.

Questions and issues respecting prior authorization have arisen in regard to innocent passage of warships and ships carrying nuclear or other inherently dangerous or noxious substances, where the principal line of division was whether coastal States should be able to require prior authorization or notification from such ships. ${ }^{39}$ The requirement of prior authorization is substantively distinct from prior notification, although, truly, the distinction is not always readily visible. Prior notification does

\footnotetext{
${ }^{33}$ France, "French Note Verbale, Nr. 1020, August 12, 2010 of the French Embassy in Canada to the Canadian Department of Foreign Affairs and International Trade" (on file with the author).

${ }^{34}$ E.J. Molenaar, "Options for regional regulation of merchant shipping outside IMO, with particular reference to the Arctic Region," Ocean Development and International Law 45, no. 3 (2014): [272-298], p. 278, based on personal communication between Molenaar and officials from Germany, France, the UK and the European Commission, mentions that also Germany, the UK and "presumably other States as well" sent Notes Verbales to Canada.

${ }^{35}$ Article 24, UNCLOS, see n. 1 above.

${ }^{36}$ Id., art. 44.

${ }^{37}$ Id., art. 42(2).

${ }^{38}$ Similarly, Article 87(1)(e) refers to the freedom of fishing, whereas Article 116 explicitly stipulates that all States have a right to fish on the high seas.

39 See J.A. Roach and R.W. Smith, Excessive Maritime Claims, 3d ed., (Leiden | Boston: Martinus Nijhoff Publishers, 2012), pp. 239-240, for a summary of the debate on the right of innocent passage of warships during UNCLOS III.
} 
not have any legal definition in the law of the sea, but under the basic understanding of the concept, it covers a requirement for a ship to send information to the coastal State before entering a specific area. Thus, a requirement of prior notification is necessarily the same as prior reporting. The crux of the requirement is to allow coastal States to be able to prepare for a potential incident involving the passing ship, but contrary to prior authorization, it does not per se presuppose coastal State authority to give or withdraw consent. To be sure, there is a possibility that the requirement of prior notification can, in practice, be assimilated with prior authorization if the failure to comply with it leads to the prohibition of entry or detention.

This concern laid at the core of the debate preceding the adoption of the Western European Particularly Sensitive Sea Area (WE PSSA) in 2003. The proposal included, among others, a requirement to comply with a reporting obligation with a 48 -hour notice period. ${ }^{40}$ The proposed ban on single-hull tankers was the key and most controversial issue of the proposal, but the initiative to adopt a 48-hour prior notification requirement also triggered strong protests from a number of traditional maritime States and a few shipping organizations. In a document submitted to the Legal Committee (LEG) by Liberia, Panama, the Russian Federation, BIMCO, ICS, International Association of Dry Cargo Shipowners (INTERCARGO), the International Association of Independent Tanker Owners (INTERTANKO) and International Parcel Tankers Association (IPTA), they expressed the view that a 48-hour notice period would inevitably lead to prohibitions of entry to the WE PSSA area, and thus would constitute an unacceptable restriction on the freedom of navigation. ${ }^{41}$ In response to these concerns, the Division for Ocean Affairs and the Law of the Sea of the United Nations (DOALOS) expressed its view that as long as the Maritime Safety Committee (MSC) adopts such a requirement, and as long as it would not be used as a basis for prohibiting entry into the PSSA area, a 48-hour prior notice would not violate the freedom of navigation. ${ }^{42}$ Eventually, the WE PSSA was adopted with a mandatory ship reporting system (SRS) for laden (crude, heavy fuel oil, bitumen or tar) tankers of more than 600 tonnes, on entry and upon leaving the area. ${ }^{43}$ The WE PSSA's proponents intended to implement a 48-hour notification, and commentators generally agree that this initiative was successful. ${ }^{44}$ It is noteworthy that the West European Tanker Reporting System (WETREP) is drafted without reference to prior "notice," "notification" or the 48-hour period, but it designates an area within which reporting is required. ${ }^{45}$

An interesting debate has surrounded transboundary movement of hazardous wastes, regulated by the 1999 Basel Convention. ${ }^{46}$ When acceding to, or ratifying the 1989 Basel Convention, some States

${ }^{40}$ IMO Doc. MEPC 49/8/1, April 11, 2003, para. 10.

${ }^{41}$ IMO Doc. LEG 87/16/1, September 15, 2003.

42 IMO Doc. LEG 87/WP.3, October 2003, attached as Annex 7 to IMO Doc. LEG 87/17, October 23, 2003.

${ }^{43}$ IMO Doc. Res. MSC 190(79), December 6, 2004.

${ }^{44}$ M.J. Kachel, Particularly Sensitive Sea Areas: The IMO's Role in Protecting Vulnerable Marine Areas (Berlin Heidelberg: Springer, 2008), p. 161; M. Detjen, “The Western European PSSA: Testing a unique international concept to protect imperiled marine ecosystems," Marine Policy 30, no. 4 (2006): [442-453], p. 444; J.P. Roberts, Marine Environment Protection and Biodiversity Conservation: The Application and Future Development of the IMO's Particularly Sensitive Sea Area Concept (Berlin Heidelberg: Springer, 2007), p. 150.

${ }^{45}$ IMO Doc. Res. MSC 190(79), December 6, 2004.

46 The Basel Convention on the Control of Transboundary Movements of Hazardous Waste and their Disposal (adopted March 22, 1989, entered into force May 5, 1992) 1673 United Nations Treaty Series 57 (1989 Basel Convention) includes a prima facie obligation of the State of export to notify the State(s) of transit of any proposed transboundary movement of hazardous wastes. However, in the face of strong opposition from some States to a requirement of prior notification, Article 4(12) includes a saving clause. This provision stipulates that the 1989 Basel Convention shall not affect existing rights and jurisdiction, and it essentially refers to the rules of UNCLOS, including sovereignty and sovereign rights in maritime zones and the exercise by ships of navigational rights and freedoms as provided for in international law. As such, the overall effect of the 1999 Basel Convention on the law of prior notification or authorization seems quite limited. 
expressed their positions in respective declarations. ${ }^{47}$ The 1989 Basel Convention did not alter the status quo. Instead, the debate surrounding the conclusion of this treaty illuminates that States are not willing to depart from their principled positions, often manifested through support for either of the two alternative positions: "no notification and no authorization," and "notification and authorization," as if the middle ground was not realistic..$^{48}$

An example of a regional instrument that explicitly includes a requirement of prior notification of transboundary movement in the territorial sea of hazardous wastes is the 1996 Izmir Protocol ${ }^{49}$ The 1996 Izmir Protocol is admittedly innovative in the sense that it expressly distinguishes the two notions through the "notification without authorization" formula. ${ }^{50}$ There is no doubt that the protocol establishes an obligation on the exporting State to notify any transiting State and that it serves as important practice supporting prior notification in international law. However, the main problem for a broader significance of this instrument is its regional character, the low adherence rate and its inter se approach..$^{51}$

Summing up, there may be good reasons for believing that the distinction between prior notification and authorization works better in theory than in practice. The 1996 Izmir Protocol was more innovative and bolder, but possibly precisely therefore, less successful. ${ }^{52}$ Having acknowledged this, the article nonetheless views prior authorization as distinct from prior notification. The latter is not free from controversies either, ${ }^{53}$ but the manner with which WETREP was adopted indicates that

47 Japan, Germany, Italy, Singapore, and the UK all declared that nothing in the 1989 Basel Convention requires
notice or consent of any State for the passage of hazardous waste on vessels exercising rights of passage in the
territorial sea or freedom of navigation through the EEZ. See the Declarations to the Basel Convention, United
Nations Treaty Collection, "Basel Convention on the Control of Transboundary Movements of Hazardous
Wastes and Deisposal, Declarations," <https://treaties.un.org/Pages/ViewDetails.aspx?src=IND\&mtdsg_no=XXVII-3\&chapter=27\&lang=en>. T. Scovazzi, "The transboundary movement of hazardous waste in the Mediterranean regional context," UCLA Journal of Environmental Law and Policy 19, no. 1 (2000): [231-245], pp. 240-241, emphasizes the radical difference between the declarations of Italy and Egypt.

${ }^{48}$ Scovazzi, see n. 47 above, p. 241.

49 Article 6(4) of the Protocol on the Prevention of Pollution of the Mediterranean Sea by Transboundary Movements of Hazardous Wastes and their Disposal (adopted October 1, 1996, entered into force January 18, 2008) (1996 Izmir Protocol).

50 See T. Scovazzi, “The Mediterranean Hazardous Wastes Protocol," European Environmental Law Review 6 (1997): [244-246], pp. 245-246, where he argues that "notification without authorization" seems fully compatible with UNCLOS.

51 G. Handl, "Preventing transboundary nuclear pollution: A post-Fukushima legal perspective," in Transboundary Pollution: Evolving Issues of International Law and Policy, eds., S. Jayakumar, T. Koh, R.C. Beckman and H. Duy Phan (Cheltenham, UK \& Northampton, MA, USA: Edward Elgar Publishing, 2015), [190-232], p. 228, notes that only 7 out of 22 contracting parties to the framework agreement, the Barcelona Convention, had ratified the protocol. See Signatures and Ratifications of the Barcelona Convention for the Protection of the Marine Environment and the Coastal Region of the Mediterranean and its Protocols as of April 24, 2019 (last notification received), available online: <http://wedocs.unep.org/bitstream/id/7f04ff0f-8108-40d5be9a-ddc95bab248d/StatusOfSignaturesAndRatifications_20190424.doc >.

${ }^{52}$ T. Treves, "Navigation of ships with nuclear cargoes: Dialogue between flag and coastal states as a method for managing the dispute," in The Oceans in the Nuclear Age: Legacies and Risks, eds., D.D. Caron and H.N. Scheiber (Leiden | Boston: Martinus Nijhoff Publishers, 2010), [217-235], describes the 1996 Izmir Protocol as an unsuccessful attempt at a compromise including prior notification without authorization and no saving clause.

53 R.R. Churchill, "The impact of State practice on the jurisdictional framework contained in the LOS Convention," in Stability and Change in the Law of the Sea: The Role of the LOS Convention, ed. A.G. Oude Elferink (Leiden | Boston: Martinus Nijhoff Publishers, 2005), [91-144], p. 118, in a very accurate manner, notes that UNCLOS is "arguably unclear or ambiguous about whether a coastal State may require prior notification of the passage of ships carrying hazardous cargoes through its territorial sea as part of its powers under Article 21." 
prior notification is scarcely distinct in substance from ship reporting. ${ }^{54}$ The latter has a firm position in the international law of the sea. ${ }^{55}$

Around twenty State parties to UNCLOS and six non-parties require warships to obtain prior authorization for passage through their territorial seas. ${ }^{56}$ The analysis of the declarations made by States upon signature or when becoming a party to UNCLOS shows different reasoning among the States for their position. Some of the States that have made declarations reserving their right to require prior authorization from warships passing through the territorial sea avoided framing the activity as innocent passage. ${ }^{57}$ Other States seem to have implied that such a requirement would be consistent with the right of innocent passage. ${ }^{58}$

It is the case that UNCLOS does not explicitly provide for the right of innocent passage of warships. ${ }^{59}$ This may explain, in large part, why prior authorization has been subject to debate. In other words, for the States that are convinced that the right of innocent passage does not apply to specific categories of ships (i.e., warships) it is consistent for them to advocate in favor of prior authorization.

UNCLOS also does not explicitly provide for the right of innocent passage of ships carrying nuclear or other inherently dangerous or noxious substances. However, Article 23 appears to assume the existence of the right as the provision imposes additional requirements for ships carrying nuclear or other inherently dangerous or noxious substances when exercising the right of innocent passage through the territorial sea. ${ }^{60}$

Nevertheless, Bangladesh, Ecuador, Egypt, Malaysia, Oman, Saudi Arabia, and Yemen have claimed the right to require prior authorization from vessels carrying radioactive materials in the declarations made under Article 310 of UNCLOS. ${ }^{61}$ Of these, Egypt, Malaysia and Saudi Arabia claim

\footnotetext{
${ }^{54}$ As asserted by H. Yang, Jurisdiction of the Coastal State over Foreign Merchant Ships in Internal Waters and the Territorial Sea (Berlin Heidelberg: Springer, 2006), p. 211; similarly in R. Pedrozo, "Encroachment on Navigational Freedoms," International Law Studies (U.S. Naval War College) 84 (2008), [85-96], p. 86.

${ }^{55}$ International Convention for the Safety of Life at Sea (adopted November 1, 1974, entered into force May 25, 1980) 1184 United Nations Treaty Series 277 (SOLAS) Regulation V/11; IMO Res. MSC 43 (64), Guidelines and Criteria for Ship Reporting Systems, December 9, 1994, as amended by Res. MSC 111 (73) and Res. MSC 189 (79); IMO Res. A.851 (20), General Principles for Ship Reporting Systems and Ship Reporting Requirements, Including Guidelines for Reporting Incidents involving Dangerous Goods, Harmful Substances and/or Marine Pollutants, November 27, 1997.

${ }^{56}$ Churchill, see n. 53 above, pp. 112-113, mentions State parties to UNCLOS: Albania, Algeria, Antigua and Barbuda, Barbados, Cape Verde, China, Grenada, Maldives, Myanmar, Oman, Pakistan, Philippines, Romania, St. Vincent and the Grenadines, Seychelles, Somalia, Sri Lanka, Sudan, Vietnam and Yemen, as well as nonparties: Cambodia, Congo, Iran, North Korea, Syria and the United Arab Emirates. As the list comes from 2005, it could be updated to reflect possible changes in State practice. However, this does not appear to be necessary here.

${ }^{57}$ See the declarations by Algeria, Ecuador and Yemen at the United Nations Treaty Collection, "United Nations Convention on the Law of the Sea, Declarations and Reservations," available online: $<$ https://treaties.un.org/Pages/ViewDetailsIII.aspx?src=TREATY\&mtdsg_no=XXI$6 \&$ chapter $=21 \&$ Temp=mtdsg $3 \&$ clang=_en $>$.

${ }^{58}$ Id.: See the declarations by China, Iran and Oman at the Declarations and Reservations.

${ }^{59}$ For reference, see Churchill, n. 53 above, pp. 111-114, who presents arguments for the existence of a right of innocent passage applicable to warships. For an interesting, although less convincing, line of argument to the contrary, see S. Jin, "The question of innocent passage of warships: After UNCLOS III" Marine Policy 13, no. 1 (1989): [56-67], pp. 60-61.

${ }^{60}$ In addition, Churchill, see n. 53 above, p. 115, mentions Article 22, which assumes tankers, nuclear-powered ships and ships carrying nuclear or other noxious substances can exercise "passage." Article 22(2) does not refer to innocent passage, but this paragraph specifies Article 22(1), which is concerned with innocent passage. Churchill refers also to the title of the Subsection A of the Section 3 of Part II of the Convention, namely "Rules Applicable to All Ships" as providing an argument that innocent passage applies to all ships, including warships and other ships regardless of the cargo.

${ }^{61}$ Declarations and Reservations, see n. 57 above. See also Treves, n. 52 above, pp. 220-221; Churchill, n. 53 above, p. 115, adds Maldives, Samoa, and Seychelles to the list.
} 
such a right until international agreements referred to in Article 23 are concluded and applicable to these States.

Other States have claimed the right to require prior authorization from ships carrying extraordinarily dangerous materials. A few States have gone so far as to prohibit passage of such vessels. ${ }^{62}$ It has been asserted that there is a gap in the law concerning the passage of ships carrying ultra-hazardous cargoes. ${ }^{63}$ In practice, ad hoc solutions have sometimes been reached through diplomacy, with ships avoiding maritime zones of some coastal States ${ }^{64}$ doing this as a matter of their liberty to choose the routes in the exercise of the freedom of navigation. ${ }^{65}$

The claims by States of a right of prior authorization have encountered substantial opposition. Some States, including Germany, Italy, the Netherlands, and the United Kingdom have explicitly expressed the view that prior authorization based on the cargo being carried is inconsistent with UNCLOS in their declarations when becoming a party to the Convention. ${ }^{66}$ Moreover, the United States and Russia clarified their position concerning prior authorization in the 1989 USSR-USA Joint Statement. Paragraph 2 of the 1989 USSR-USA Joint Statement reads:

All ships, including warships, regardless of cargo, armament or means of propulsion, enjoy the right of innocent passage through the territorial sea in accordance with international law, for which neither prior notification nor authorization is required.$^{67}$

Summing up, where a navigational right applies ${ }^{68}$ prior authorization would be inconsistent with the duty to not hamper or deny it. ${ }^{69}$ Some States, however, maintain either that specific categories of ships do not enjoy the right of innocent passage or that the requirement of prior authorization can qualify the innocent passage right. While noting the lack of uniformity of State practice, nevertheless it is submitted that claims to prior authorization in the context of innocent passage rights based solely on cargo or status as a military vessel are not supported by UNCLOS. At the same time, such claims result in certain political pressure that can be ultimately successful (i.e., lead to change of behavior).

62 J.M. Van Dyke, "The legal regime governing sea transport of ultrahazardous radioactive materials," Ocean Development and International Law 33, no. 1 (2002): [77-108], p. 86; M. Roscini, "The navigational rights of nuclear ships," Leiden Journal of International Law 15 (2002): [251-265], passim.

${ }^{63}$ S. Kaye, "Freedom of navigation in a post 9/11 world: Security and creeping jurisdiction," in The Law of the Sea: Progress and Prospects, eds., D. Freestone, R. Barnes and D. Ogin (Oxford: Oxford University Press, 2009), [347-364], p. 362, provides a table of States that have objected to nuclear ships passing through the territorial sea and the EEZ. It features 27 States, including traditional proponents of the freedom of navigation, such as Singapore. This shows that the tensions regarding passage of such vessels exist in general, and the claim of prior authorization is simply one method adopted by States to protect their interests.

${ }^{64}$ For instance, the shipment of radioactive materials by the Pacific Pintail, the Pacific Teal, the Pacific Swan and the Akatsuki Maru drew fierce protests from many States. These voyages were completed, but the result of the protests is that many such shipments use longer routes, avoiding exercising navigational rights in a confrontational manner. See J. Kraska, Maritime Power and the Law of the Sea: Expeditionary Operations in World Politics (New York, Oxford: Oxford University Press, 2011), pp. 344-345.

${ }^{65}$ See Treves, n. 52 above, pp. 225-226, where he draws conclusions on State practice.

${ }^{66}$ Declarations and Reservations, see n. 57 above.

${ }^{67}$ Union of Soviet Socialist Republics - United States of America: Joint Statement with attached uniform Interpretation of Rules of International Law governing Innocent Passage (September 23, 1989) 28 International Legal Materials 1444 (1989 USSR-USA Joint Statement).

${ }^{68}$ Treves, see n. 52 above, p. 217, argues that ships carrying radioactive materials enjoy the right of innocent passage, although he notes that it has been occasionally argued, for example by Iran, that such passage can be "prejudicial to the peace, good order or security of the coastal State." Churchill, see n. 53 above, pp. 111-118, provides a convincing line of argument that warships and ships carrying hazardous waste enjoy the right of innocent passage. His conclusions on prior authorization frame the requirement as contrary to UNCLOS, regardless of the divergent practice of some other States in that respect.

${ }^{69}$ Handl, see n. 51 above, p. 221; Churchill, see n. 53 above, p. 118. 
Having said this, notably, Russia is one of the States that has expressly dismissed the right for coastal States to request prior authorization for ships in innocent passage. ${ }^{70}$

\section{PRIOR AUTHORIZATION AND ARTICLE 234}

It has been argued that Article 234's due regard clause introduces a sui generis regime of navigation, giving more weight to environmental considerations than the established navigational regimes do.$^{71}$ If that is the case, prior authorization could be justified by Article 234, even if apparently inconsistent with the traditionally framed navigational rights and freedoms. This discussion purports to evaluate the reasonableness of the measure.

\section{Key Functions of the Permit Scheme Practiced by Russia on the NSR}

To understand the goals of prior authorization, as pursued in the practice of Russia, it is helpful to look in detail at the information requested in the application for a permit to navigate through the NSR. Three key elements, or functions, of the NSR prior authorization emerge. The first is the requirement to provide information about the ship,$^{72}$ and its voyage outside the NSR, especially the ports of call directly before and after having navigated the NSR ${ }^{73}$ The second is the requirement to provide details of the intended itinerary within the NSR. ${ }^{74}$ The third is the requirement to provide copies of the relevant certificates. ${ }^{75}$ The ANSR grants a permit when the ship submits copies of the classification certificate, the tonnage certificate, and documents certifying availability of insurance of civil liability for pollution damage or any other damage inflicted by the ship, such as the CLC and the CLBC. As part of the implementation of the Polar Code, the ANSR also requires a copy of a Polar Ship Certificate.

As noted above, the granting of a permit is dependent on the formal submission of all information required under the first element. The substance of the information does not have any effect on the decision. It is questionable whether Russia, as a matter of its prescriptive jurisdiction under Article 234, can require the submission of such information. In particular, it is not clear how the information about the voyage outside the NSR relates to the purpose of Article 234. Even if Russia requires all of this information, the Russian legislation does not appear to allow the ANSR to reject an application based on the substance of the information regarding a ship and its voyage outside the NSR. ${ }^{76}$ As such, the submission of the information for the first element does not necessarily justify the prior authorization scheme - the same can be achieved by reporting or notification.

The substance of the information required under the second element is more relevant for a decision, as the ANSR approves the plan of the voyage only if the plan conforms to the zonal division of the NSR. Also, the ANSR, based on the intended voyage plan, indicates whether icebreaker assistance is required. It is noteworthy that the Polar Code devotes Chapter 11 to Voyage Planning. The goal of Chapter 11, as expressed in paragraph 11.1 is "to ensure that the Company, master and crew are provided with sufficient information to enable operations to be conducted with due

701989 USSR-USA Joint Statement, see n. 67 above. Notably, it was Russia that protested against prior notification as part of WE PSSA, see n. 41 above.

${ }^{71}$ K. Bartenstein, "The 'Arctic Exception' in the Law of the Sea Convention: A contribution to safer navigation in the Northwest Passage?" Ocean Development and International Law 42, no. 1-2 (2011): [22-52], p. 45.

${ }^{72}$ Item 4(1) of the 2013 Rules (see n. 6 above), and Items 1-5 of Annex 1 of the 2013 Rules.

${ }^{73}$ Id., and Items 6-7 of Annex 1 of the 2013 Rules.

${ }^{74}$ Id., and Items 8-9 of Annex 1 of the 2013 Rules.

75 Items 4(2-(4) of the 2013 Rules (see n. 6 above).

${ }^{76}$ In summer (i.e., July to 15 November) any vessel can enter the NSR, provided they have obtained the relevant certificates, which are contingent on fulfilling substantive requirements. Outside this period, vessels need to have a minimum ice class of Arc4. See n. 11 above. 
consideration to safety of ship and persons on board and, as appropriate, environmental protection." Under this Chapter, the master of the ship is to take into account the potential hazards to navigation in the voyage plan. In particular, the discretion of the vessel's master to plan the voyage is limited, as they must take into account the following:

- the procedures required by the Polar Water Operational Manual (PWOM);

- any limitations of the hydrographic information and aids to navigation available;

- current information on the extent and type of ice and icebergs in the vicinity of the intended route;

- statistical information on ice and temperatures from former years;

- places of refuge;

- current information and measures to be taken when marine mammals are encountered relating to known areas with densities of marine mammals, including seasonal migration areas;

- current information on relevant ships' routing systems, speed recommendations, and vessel traffic services relating to known areas with densities of marine mammals, including seasonal migration areas;

- national and international designated protected areas along the route; and

- operation in areas remote from search and rescue (SAR) capabilities. ${ }^{77}$

Ships navigating in the NSR are subject to the regulations on voyage planning included in the Polar Code, as well as the specific 'Criteria on the Admissibility of Ships to the Northern Sea Route in Accordance with Ice Class' in Annex 2 of the 2013 Rules. The decisions from the ANSR concerning the grant or refusal of a permit do not appear to rely on any additional discretion beyond what the 2013 Rules stipulate. Even the indication of whether the ship requires icebreaker assistance stems directly from the matrix of the zonal division, ice class, period of navigation and ice conditions, rather than is determined in an individual decision by the ANSR. Thus, the submission of information regarding the intended itinerary does not appear to necessitate the authorization from the coastal State either. The ANSR does not have any discretion concerning a determination of the consistency of the intended voyage plan with the regulations, as Annex 2 of the 2013 Rules sets out the operational limits for specific categories of ships in a transparent manner. The decisions of the ANSR are based on the application of the regulations.

The third element - involving verification of compliance with international rules and standards, the evidence of which is provided by possession of valid certificates on-board the respective vessel appears to be the primary consideration respecting prior authorization as practiced by Russia on the NSR. The main benefit of the prior authorization scheme, in light of the purpose of the prevention, reduction and control of vessel-source pollution, is the ability of the coastal State to verify the validity of relevant certificates.

Then, does the scheme of prior authorization as practiced by Russia constitute a substantive requirement and burden on a foreign vessel, or is it a form of enforcement jurisdiction? It would appear that it predominantly serves as an additional layer of verification that ships be in compliance with other substantive requirements included in the 2013 Rules, as well as requirements arising from international instruments, such as civil liability insurance and the Polar Ship Certificate. Thus, the Russian practice more closely resembles the exercise of enforcement jurisdiction.

\section{Possible Arguments in Favor of Prior Authorization}

On the face of it, the Russian prior authorization scheme appears to be useful in preventing vessels that are not well suited to Arctic conditions from entering the potentially hazardous waters of the NSR. As

\footnotetext{
${ }^{77}$ Para. 11.3 of the Polar Code, see n. 7 above.
} 
long as it is applied even-handedly, the prior authorization scheme is likely to decrease the potential risks of vessel-source pollution occurring, and thus arguably fits the purpose of Article 234. The prior authorization burden minimally interferes with the exercise of navigation, when approached in the context of the need for special planning before an Arctic voyage. Russia's practice has tended to facilitate foreign navigation rather than restrict it. ${ }^{78}$

Article 234 would support prior authorization, should it be necessary for or clearly tied to the prevention of vessel-source pollution. Russia has not engaged in any publicly available discussions stating clearly the underlying rationale of the 2013 Rules, but officials have pointed to Russia's responsibility to adopt different measures to prevent vessel-source pollution, including the permission procedure. ${ }^{79}$ Russian academics analyzing Article 234 have emphasized the responsibility of Arctic coastal States to protect and preserve the unique Arctic marine environment and ecosystems. ${ }^{80}$

The notion of such a legal responsibility relates to the principle of prevention, set out in Principle 21 of the 1972 Stockholm Declaration and Principle 2 of the 1992 Rio Declaration, the latter considered a rule of customary international law by the ICJ ${ }^{81}$ albeit in a very different context. The key element of this principle is that States have a responsibility to ensure that activities within their jurisdiction or control do not cause damage to the environment of other States or areas beyond the limits of national jurisdiction. However, since the principle of prevention is reflected in various provisions of UNCLOS, it is not clear how much it adds to the interpretation of Article 234. ${ }^{82}$

There is also the precautionary approach, of which the most accepted expression is found in Principle 15 of the 1992 Rio Declaration:

[i]n order to protect the environment, the precautionary approach shall be applied by States (...). Where there are threats of serious or irreversible damage, lack of full scientific certainty shall not be used as a reason for postponing cost-effective measures to prevent environmental degradation. ${ }^{83}$

Setting aside the controversy regarding its normative status in international law and that it is not included in UNCLOS, the precautionary approach can add a layer of complexity for the coastal State's decision-making which, in the context of the application of Article 234, should be closely linked with scientific evidence. In a scenario where the available scientific evidence is insufficient, the precautionary approach indicates caution to be exercised to mitigate the risk of an activity, such as shipping. The precautionary approach should play a role in how Arctic coastal States manage shipping in their ice-covered areas. However, in consideration of the controversy surrounding unilateral exercises of coastal State jurisdiction in the Arctic and the concerns of other States about the abuse of Article 234 powers, it would be more reasonable and legitimate to push for extensive implementation

\footnotetext{
${ }^{78}$ See Solski 2020, n. 12 above.

${ }^{79}$ Viktor Olersky, deputy Minister of Transport, "The application of the Polar Code in the Russian Federation," a presentation at the International Conference on Harmonized Implementation of the Polar Code, February 22, 2018, Helsinki, Finland.

${ }^{80}$ For example, I.N. Mikhina, "Sovremennye Problemy Mezhdunarodno-pravovoi Zashity Vod Arktiki [Modern Issues of International Legal Protection of Arctic Waters]," in Mezhdunarodnoe Morskoe Pravo: Statii Pamyati A.L. Kolodkina, eds. R.A. Kolodkin and S.M. Punzhin (Moscow: Statut, 2014), [254-278], p. 264.

${ }^{81}$ See P. Birnie, A. Boyle and C. Redgwell, International Law and the Environment, 3d ed. (Oxford: Oxford University Press, 2009), pp. 137-140.

${ }^{82}$ Although not addressed in this article, one may consider the principle of prevention as embodied in the ILC 2001 Draft Articles on Prevention of Transboundary Harm from Hazardous Activities, annexed to United Nations General Assembly Resolution 62/68, of January 8, 2008. In particular, Article 6 sets forth an obligation to require prior authorization for any activity within the scope of the Articles. However, keeping in mind Article 94(1) of UNCLOS, should the passage of a ship fall under the scope of the ILC Draft Articles, the duty to require prior authorization would primarily rest on the flag State, as long as the ship would exercise a navigational right.

${ }^{83}$ United Nations Convention on Environment and Development, Rio Declaration on

Environment and Development, UN Doc. A/CONF.151/26/Rev.1 (Vol. I) (12 August 1992),
}

Annex I. 
of the principles of the environmental law in multilateral settings, such as the IMO, despite the fact that this has been previously requested by both Canada and Russia.

From a practical point of view, prior authorization in the Arctic does not constitute a major burden on ships as it may elsewhere. Since navigation in Arctic ice-covered areas is always an extraordinary endeavor, it requires special preparations. Normally, ships can change their planned itineraries as and when they wish. Therefore, it is essential that they be, in principle, free to navigate without necessarily being compelled to familiarize themselves with specific rules applicable to maritime zones in different coastal States. Arctic navigation, however, requires special planning because vessels may be exposed to exceptional risks. This is reflected in the section on voyage planning of the Polar Code ${ }^{84}$ as well as in the practice of underwriters, which may require a ship-owner to take specific additional preventative or precautionary measures before engaging in navigation on the NSR. ${ }^{85}$ The requirement to obtain a permit from the ANSR may not constitute a significantly additional, and thereby unacceptable burden, but rather is just another element in the process of planning for a voyage.

Further, one can note that Russia's practice concerning prior authorization for navigation on the NSR has become significantly less burdensome since the adoption of the 2013 Rules. The ANSR grants authorization upon the verification of documents, without the need for a vessel's inspection. No vessels have had problems in obtaining a permit, ${ }^{86}$ and the practice of the ANSR has adapted so that it grants permits for extended periods of up to one year, rather than for specific voyages. ${ }^{87}$ For the companies interested in operations on the NSR, such a procedure provides certainty and predictability for their plans for an entire season. The procedure is transparent, and the outcome of the process appears to be predictable. Also, under the 2013 Rules, the ANSR has no discretionary power to refuse a permit if all the substantive requirements are met. Under the 2013 Rules, the only example to the contrary was the refusal of the fourth application by the Arctic Sunrise ${ }^{88}$ which was clearly a special circumstance.

\section{Arguments Against Prior Authorization}

The principal problem with the prior authorization scheme is that the requirement is irreconcilable with navigational rights and freedoms, as set out in the general navigational provisions in UNCLOS. The issue that is raised by prior authorization is not how Russia executes it, but whether Russia has a right to put such a scheme into place at all. Prior authorization, regardless of how transparent and unproblematic, arguably introduces a reversal of the burden of proof for compliance with substantive requirements. Navigation, as an exercise of a right or freedom, is prima facie lawful unless there is evidence to the contrary. The prior authorization scheme as practiced by Russia on the NSR shifts the burden of proof to the ship (and hence to the flag State) by demanding that the vessel comply with substantive requirements and possess necessary certificates on board. Although such precaution may bring short-term benefits by eliminating risk-prone ships from entering the area, it is inconsistent with the cornerstone of the law of the sea, navigational rights and freedoms, all construed as 'rights.' Under the existing rules of the law of the sea on navigation, prior authorization is lawful only in areas that are not subject to navigational rights, i.e., internal waters, unless subject to innocent passage.

\footnotetext{
${ }^{84}$ See n. 7 above (Polar Code), para. 11.3.

${ }^{85}$ The UK P\&I Club, for example, requires ship-owners to obtain an appropriate Ice or Polar Class, receive approval from hull underwriters, and clarify the intended route with cargo owners. See "Arctic Shipping: the Northern Sea Route FAQs," UK P\&I Club, available online: <https://www.ukpandi.com/fileadmin/uploads/ukpi/Documents/Polar__ice_navigation/Arctic_Shipping_The_Northern_Sea_Route_FAQS.pdf $>$.

${ }^{86}$ Figure 1 shows that the ratio of rejected applications has gradually dropped to a minimum.

${ }^{87}$ One example of such practice is the permit granted to the Christophe De Margerie (Cyprus), on January 18, 2018, valid until February 8, 2019; see Ministry of Transport of the Russian Federation, Federal Agency of Maritime and River Transport, Federal State Institution the Northern Sea Route Administration, Permit No. 2/7, January 18, 2018.

${ }^{88}$ See n. 14 above.
} 
The law of the sea does not allow for "pre-emptive" verification of whether ships in lateral (innocent or transit) passage and a fortiori those exercising the freedom of navigation, carry the necessary documents on board. This is in line with the concept of the freedom of navigation complemented by the primacy of flag State jurisdiction.

UNCLOS and relevant IMO instruments recognize the flag State as having the primary duty to ensure that a vessel carries the relevant documents on board. As regards prescriptive jurisdiction, the flag State's duty to exercise effective control and jurisdiction over its vessels is set out in Article 94 of UNCLOS. Regarding enforcement jurisdiction, Article 217(3) of UNCLOS imposes a duty on the flag State to ensure the appropriate surveying and certification of vessels. Contemplating the need for a mechanism of checks and balances, the law of the sea recognizes that port State control has a key role in verifying compliance with relevant rules regarding vessels' surveying and certification. The powers of the port State stem from its sovereignty, as reflected in the right to prescribe conditions for admission to port under Article 25(2) of UNCLOS. The power to inspect the vessel may, under the conditions set out in Article 219 of UNCLOS, lead to the duty to take administrative measures to prevent an unseaworthy vessel from sailing. Port State control has been recognized in the relevant international maritime instruments, such as SOLAS Regulation I/19, ${ }^{89}$ Article 5 of MARPOL, ${ }^{90}$ Article 12 of the 1969 Tonnage Convention, ${ }^{91}$ and Article VII (11) of the CLC Convention. ${ }^{92}$ None of these instruments includes any reference to coastal State powers to examine the possession of certificates on board a ship that is not seeking to enter internal waters.

Paradoxically, under the previously applicable legal regime of navigation on the NSR, Russia could rely on a more solid legal basis of port State jurisdiction to verify the possession of relevant certificates in ports. Under Item 2.11 of the 1996 Requirements for the Design, Equipment, and Supplies of Vessels Navigating the NSR, the physical inspection of the vessel to verify compliance with substantive requirements was mandatory in certain Russian ports (Murmansk, Nakhodka, Vladivostok or Provideniya). ${ }^{93}$ Although it is evident that the 2013 Rules introduced a much more liberal scheme for the online submission of the relevant documentation, the fact that the vessel can navigate through the NSR without entering a Russian port means that Russia is unable to exercise port State jurisdiction.

In addition to the general obligation of a flag State to ensure that its vessels carry certificates required by applicable international rules and standards, Article 23 of UNCLOS imposes a more specific duty on foreign nuclear-powered ships and ships carrying nuclear or other inherently dangerous or noxious substances to carry relevant documents as established by international agreements. It is beyond the scope of this article to investigate the problems surrounding the practical application of this provision, but there is no consensus on the question of whether the failure to carry the documents required by Article 23 means that the ship is not entitled to the right of innocent passage. ${ }^{94}$ The main point here is that even with a view to verifying compliance with Article 23 , the coastal State cannot ascertain the possession of the necessary documentation by the ship without

${ }^{89}$ SOLAS, n. 55 above, Regulation I/19.

${ }^{90}$ International Convention for the Prevention of Pollution from Ships (adopted November 2, 1973, as amended by the Protocol of 1978, entered into force October 2, 1983) 1340 United Nations Treaty Series 61 [MARPOL].

${ }^{91}$ International Convention on Tonnage Measurement of Ships, 1969 (adopted June 23, 1969, entered into force July 18, 1982) 1291 United Nations Treaty Series 3.

${ }^{92}$ International Convention on Civil Liability for Oil Pollution Damage (adopted November 29, 1969, entered into force June 19, 1975, replaced by 1992 Protocol, adopted November 27, 1992, entered into force May 30, 1996) 973 United Nations Treaty Series 3.

${ }^{93} 1996$ Requirements for the Design, Equipment, and Supplies of Vessels Navigating the NSR, English version published in the Guide to Navigating through the Northern Sea Route, Head Department of Navigation and Oceanography of the Ministry of Defense of the Russian Federation, St. Petersburg, pp. 317-323.

${ }^{94}$ Yang, see n. 54 above, p. 177, is of the opinion that innocent passage can hardly be denied to a ship, even when found to have breached a duty to carry necessary files. R. Barnes, "Article 23" in United Nations Convention on the Law of the Sea, A Commentary, ed., A. Proelss (Munich: C.H. Beck, Hart, Nomos, 2017), [213-217] argues to the contrary. 
interfering with the passage. ${ }^{95}$ Coastal State enforcement jurisdiction under Articles 25 and 220 can be triggered only after the coastal State obtains knowledge leading it to believe that a violation has taken place. In the context of vessel-source pollution, only an act of "wilful and serious pollution" can lead the coastal State to determine that the right of innocent passage no longer exists. Therefore, presumably, the lack of certificates compulsory under SOLAS, MARPOL, CLC, and CLB would not be sufficient to result in a similar situation. ${ }^{96}$

The question is whether the authority to verify possession of relevant certificates on board falls within the ambit of Article 234. In addressing this issue, it is helpful to note how the general rules of Part XII of UNCLOS deal with the examination of documents. Article 220 introduces a tiered threshold for coastal State enforcement. Under Article 220(2), in the territorial sea, the coastal State can undertake a "physical inspection" of the vessel only after there are "clear grounds for believing" that a violation took place. While a physical inspection would traditionally involve at-sea boarding by the coastal State enforcement authorities, Article 226 essentially defines a "physical inspection" as "an examination of such certificates, records or other documents as the vessel is required to carry by generally accepted international rules and standards [GAIRAS]." In the EEZ, the exercise of coastal State enforcement jurisdiction depends on the gravity of the violation of applicable international rules and standards for the prevention, reduction, and control of vessel-source pollution. Unless the coastal State has "clear grounds for believing" that the violation resulted in a "substantial discharge causing or threatening significant pollution of the marine environment," it may, pursuant to Article 220(3), require the vessel to give "information regarding its identity and port of registry, its last and next ports of call, and other relevant information required to establish whether a violation has occurred."

As discussed above, the power to verify whether a ship carries the necessary documentation lies beyond coastal State jurisdiction under the general rules of the law of the sea, except for instances triggering coastal State enforcement jurisdiction. The construction of the most fundamental rules of the law of the sea on navigational rights and the notion of enforcement jurisdiction are rooted in the distinction between the power to prescribe and the power to enforce. Article 234, in an unprecedented manner, refers to both in a single sentence. It is submitted that this should not be read as affecting the basic understanding of the distinction. It may be necessary for the prevention, reduction, and control of vessel-source pollution that the coastal State prescribes the possession of relevant, valid certificates, such as those of insurance. Notably, the Polar Code does not address the issue, and it might be a sound policy on the part of the coastal States to utilize their powers under Article 234 to prescribe possession of valid documents certifying the availability of insurance for civil liability for pollution damage or any other damage inflicted by the ship in ice-covered areas. Under Article 234, the coastal State can enforce violations with such a rule, but "pre-emptive" enforcement would be at odds with the presumption of lawfulness of navigation owed to ships exercising their navigational rights and freedoms. A lawful exercise of Article 234 powers could be to require the possession of the relevant documents from ships intending to navigate the NSR. A more acceptable way of monitoring whether ships comply with the prescription could be a procedure of prior notification, subject to proportionate enforcement after a violation has taken place.

Even under the assumption that prior authorization may be a necessary preventative measure, the lax Russian enforcement of the requirement to obtain a permit appears to undermine the strength of the argument. At the time of writing, the 2013 Rules had been in effect for seven navigational seasons. During this period, many ships did not comply with the permit requirement. ${ }^{97}$ There have been instances where ships have entered the NSR without a valid permit from the ANSR and instances where ships navigated in violation of the terms indicated in the permit, such as the area, period, or

\footnotetext{
${ }^{95}$ Id. (Yang), p. 177.

${ }^{96}$ International Convention on Civil Liability for Bunker Oil Pollution Damage, 2001 (the

Bunkers Convention), Official Journal L 256, 25/09/2002, p. 9-16.

${ }^{97}$ See the discussion in Solski 2020, n. 12 above.
} 
need for icebreaker assistance. In many cases, it appears that the ships were permitted to continue their voyages and obtained permits after disclosure of the violation. ${ }^{98}$

The emerging picture is that the requirement to obtain a permit has frequently been violated, but violations have not often been penalized. The lack of sufficient enforcement might be just a temporary situation, as the Russian authorities may eventually bolster the capacity of the enforcement agencies, and perhaps clarify the relevant procedures. Insufficient or imperfect exercise of enforcement jurisdiction, in principle, should not be viewed as a factor compromising the exercise of prescriptive jurisdiction. However, the obscurity surrounding the Russian legislative framework for enforcement, as well as the practice, may suggest that the requirement to obtain prior authorization may be prone to selective adherence and enforcement. The lack of clarity respecting the consequences of a violation of the requirement may raise doubts about the adherence to the non-discrimination principle in Article 234. In that respect, an important step to ensure compliance with the duty of non-discrimination would be for the coastal State (Russia and Canada) to clarify the rules and procedures for enforcement. Otherwise, the risk exists that selective enforcement practice may favor some users over others and hence, undermine the prohibition of discrimination. Also, this may cast doubt on the intention of the requirement, potentially selectively enforced against 'unwanted' ships like the Arctic Sunrise, as well as the added value of the requirement for the prevention of vessel-source pollution. Imprecise rules and procedures for enforcement may have led, in some cases, to under-reaction or overreaction of the relevant authorities.

Based on the above, a requirement for prior authorization would not be consistent with Article 234. Moreover, the strength of possible arguments underlining the usefulness or necessity of prior authorization for the prevention of vessel-source pollution has arguably decreased with the adoption of the Polar Code. The strength of those arguments can be expected to decrease further, as the Polar Code is successfully and effectively implemented by flag States and the industry. Prior to the adoption of binding international rules and standards, the argument that it was necessary for coastal States to maintain close control over which vessels were permitted to navigate in ice-covered areas was persuasive. It would have been naive to expect all flag States to conform to non-binding IMO guidelines for navigation in polar waters and exercise effective control and jurisdiction over their vessels. The latter issue can still pose some challenges, linked to the general concern over the effective control and jurisdiction exercised by some flags of convenience. One can argue that in the early days of the operation of the Polar Code, with ensuing uncertainty over its proper and effective implementation, prior authorization may still play an important role in preventing vessel-source pollution.

One can also assume that the general tolerance of other States to the measure might change with an increase in regular use of the NSR by foreign ships. So far, most of the international shipping using the NSR has been of an experimental character. New stakeholders, States or companies, have yet to develop their visions as to whether and how they may want to operate on the NSR, gain experience, and possibly refine their positions on the legality of different practices. From a practical point of view, Russia's assistance will be instrumental for successful operation in the Russian Arctic and it may be a key factor for the success of large-scale projects. It is unlikely that those States and stakeholders, like shipping companies, that are genuinely interested in the regular use of the NSR will openly defy or challenge Russian rules. It may serve their interests to negotiate with Russia. It may be in Russia's interest to discourage other States from challenging its regulatory system. The analysis of Russian practice shows that Russia has adopted a policy to keep the regulatory burden to a minimum through a streamlined and transparent system of fast and predictable decision-making, based on online applications. It is difficult to predict whether future users of the NSR would accept a Russian requirement of prior authorization as reasonable and justifiable. 


\section{CONCLUSION}

This article's main objective is to answer the question whether prior authorization is consistent with Article 234. Considering the vague standard of reasonableness of Article 234, it is difficult to give an absolute answer. However, the analysis of Russia's relevant practice in the context of the global controversy surrounding the notion of prior authorization does not allow for the conclusion that the measure is sufficiently useful in meeting the objectives of Article 234 so as to overturn the apparent incompatibility with navigational rights and freedoms.

The critical problem with prior authorization is that it shifts the burden of proof that navigation is lawful onto the flag State. Although the measure might offer an effective means to prevent vesselsource pollution, the argument put forward here is that it is inconsistent with the fundamental understanding of navigational rights and freedoms. While not fully explored in this article, it seems reasonable to suggest that a prior notification scheme without the element of authorization could offer a better alternative to the Russian scheme currently in place. ${ }^{99}$

The solution envisaged is premised on the presumption of compliance, in which what is required is for the shipmaster to transmit the notification to the ANSR with all the relevant information about the ship and the voyage, as well as the documents certifying the ice classification and availability of civil liability insurance. The difference with the current regime would be that the ANSR would not be able to grant or refuse access, but instead could make recommendations on icebreaker assistance or ice pilotage, as well as on the itinerary. As a matter of prescriptive jurisdiction under Article 234, the coastal State can incorporate the requirement to follow the PWOM or an alternative scheme. If the ship fails to comply with the requirements, the coastal State could then take enforcement action.

The benefits of the current prior authorization scheme include the ability of the coastal State to keep track over when and where it can expect ships of different characteristics to operate. It is preferable that vessels unsuited to Arctic conditions be barred from entering the potentially hazardous waters of the NSR. Also, the application procedure gives the coastal State an overview of planned activity in different sectors of the NSR, which should be relevant for decision-making on the allocation of resources, such as the number of icebreakers to be ready to respond to emergencies. However, the same appears to be achievable through a system of prior notification without authorization. Moreover, the Polar Code already imposes particular limitations on the discretion of ships to choose their itineraries, ${ }^{100}$ and it does not appear to be necessary for the coastal State to duplicate this.

In essence, the argument is that to bring Russian legislation into conformity with Article 234, Russia would need to relinquish its claim that navigation on the NSR is subject to its consent. In the context of the long history of the NSR, which has not been used by foreigners without the consent of the Soviet Union/Russia because of the tacit understanding of the Soviet monopoly over merchant shipping in the NSR before $1991,{ }^{101}$ and the requirement of prior authorization after $1991,{ }^{102}$ such a decision may be difficult. As regards the other potential motives for Russian policy to maintain prior authorization for the entire NSR, the requirement may serve a symbolic role to underline the continuity of exercised control over the area. Keeping the requirement may be strategically important for several reasons. It marks the continuity of Russia's control over the NSR, ${ }^{103}$ and it keeps a lid on the discussion of the applicable navigational rights through straits enclosed with straight baselines. ${ }^{104}$ Moreover, the maintenance of the prior authorization scheme for the NSR can be perceived in Russia

\footnotetext{
99 The idea is attractive, although not without weaknesses. See the discussion above.

100 See n. 7 above (Polar Code), para. 11.3.

${ }^{101}$ See J. Solski, "New Russian legislative approaches and navigational rights within the Northern Sea Route (NSR)," Yearbook of Polar Law Yearbook of Polar Law 12, no.1 (2020): 228-250, for an overview of the Soviet/Russian historical policies and practices to keep control over the NSR.

102 Id.

${ }^{103}$ Id.

${ }^{104} \mathrm{Id}$
} 
as bolstering the argument of the 'national' status of the NSR, ${ }^{105}$ even if the legal implications of the latter have never been fully articulated.

It is possible that Russia's practice will meet with foreign acquiescence. As observed above, foreign ships that use the NSR normally comply with Russian requirements. If such practice continues and other States do not reject Russia's prior authorization scheme, the Russian and Canadian interpretation that Article 234 allows for prior authorization may become accepted and opposable to third States as a matter of law.

The application of a consent-based regime on the NSR also raises a more general issue of to what extent Russia maintains a consistent approach to international law. While Article 234 provides for an unprecedented regime of navigation in ice-covered areas, there appears to be some dissonance between Russia's views on the substantive scope of coastal State jurisdiction outside the NSR, where Russia's maritime interests prevail, while within the NSR, strong coastal State interests prevail. Russia has for decades aligned with the maritime and naval States, defending the freedom of navigation in a way that benefitted Russia's ships. ${ }^{106}$ Adopting a requirement of prior authorization within the vast area of the NSR appears to be at odds with Russia's strong opposition to prior authorization in areas where it is a flag State. ${ }^{107}$ Russia is not the only State that pursues an apparent double standard in the international law of the sea. But attention may need to be given to the apparent inconsistency. The argument developed here is that the prior notification requirement presents itself as a better solution than prior authorization, one that would arguably be more compatible with Article 234 and still provide the coastal State with the ability to monitor shipping along the NSR.

${ }^{105}$ Note that Article 14 of the federal law on the internal sea waters, territorial sea and contiguous zone of the Russian Federation, July 31. 1998, No. 155-FZ, SZRF, August 3, 1998, No. 31 p. 3833, describes the NSR as a "historically developed national transport line of communication of the Russian Federation."

${ }^{106}$ Here one can once again refer to the 1989 USSR-USA Joint Statement, see n. 67 above; see also the discussion surrounding the WE PSSA and Russia's position in that regard in n. 41 above. ${ }^{107} \mathrm{Id}$. 